\title{
Pengaruh stres kerja dan konflik kerja terhadap semangat kerja karyawan pabrik
}

\author{
Asri Hidayat*, Arwinence Pramadewi, \& Ahmad Rifki
}

Fakultas Ekonomi dan Bisnis, Universitas Riau, Indonesia

\begin{abstract}
Abstrak Penelitian ini bertujuan untuk mengetahui pengaruh stres kerja dan konflik kerja terhadap semangat kerja karyawan. Ada tiga variabel yang diteliti, yaitu stres, konflik, dan semangat kerja. Metode pengambilan sampel dilakukan dengan cara sensus sebanyak 87 orang. Pengambilan data dengan cara wawancara dan pengumpulan kuesioner. Penelitian ini menggunakan analisis regresi linear berganda, uji kualitas instrumen penelitian, uji asumsi klasik, dan hipotesis yang diolah menggunakan program SPSS. Hasil penelitian ini menunjukkan bahwa stres kerja dan konflik kerja secara simultan berpengaruh terhadap semangat kerja. Secara parsial, stres kerja berpengaruh negatif dan signifikan terhadap semangat kerja. Begitu pula konflik kerja secara parsial berpengaruh negatif dan signifikan terhadap semangat kerja. Penelitian ini telah dapat mengungkapkan hubungan semangat kerja dengan stres dan konflik kerja pada satu perusahaan.
\end{abstract}

Kata kunci: stres kerja; konflik kerja; semangat kerja

\begin{abstract}
This study aims to determine how the influence of job stress and work conflict on factory employee morale. We studied three variables, namely job stress, work conflict, and work spirit. The method of determining samples is done by the census, with the number of samples is 87 respondents. Retrieving data was done by interview and collecting questionnaires. While in terms of data analysis, this study uses multiple linear regression analysis. To test the quality of research instruments we used classic assumption tests and hypotheses that are processed using SPSS. The results of this study indicate that job stress and work conflict simultaneously have a significant effect on morale, job stress partially has a negative and significant effect on morale, and work conflict partially has a negative and significant effect on work morale. This research can reveal the relationship of work spirit with stress and work conflict in an enterprise.
\end{abstract}

Keywords: job stress; work conflict; work spirit

JEL Classification: J28; J53; L25 


\section{PENDAHULUAN}

Pada perkembangan globalisasi, banyak perusahaan dituntut untuk dapat memaksimalkan kinerja karyawan yang lebih baik. Karena di zaman globalisasi perusahaan-perusahaan di Indonesia terus mengalami persaingan yang begitu ketat sehingga perusahaan harus lebih meningkatkan kinerja perusahaannya. Hal ini terutama pada bagian Sumber daya manusia (SDM) untuk menghadapi persaingan yang sangat ketat. Masalah sumber daya manusia menjadi perhatian yang sangat penting bagi perusahaan untuk tetap bertahan. Perusahaan dituntut untuk memperoleh, mengembangkan, dan mempertahankan SDM yang berkualitas.

Oleh karena itu sumber daya manusia merupakan aset yang harus ditingkatkan secara efektif dan efisien sehingga akan terwujud kinerja yang optimal. Untuk mencapai tujuan organisasi dalam hal ini perusahaan harus mampu menciptakan situasi dan kondisi yang mendorong dan memungkinkan karyawan untuk mengembangkan kemampuan dan keterampilan secara optimal, khususnya dalam hal kinerja.

Sumber daya manusia merupakan potensi yang terkandung dalam diri manusia untuk mewujudkan perannya sebagai makhluk hidup sosial yang adaptif dan transformatif. Sumber daya manusia mampu mengelola dirinya sendiri serta seluruh potensi yang terkandung di alam menuju tercapainya kesejahteraan kehidupan dalam tatanan yang seimbang dan berkelanjutan. Perkembangan terbaru saat ini memandang sumber daya manusia bukan lagi sumber daya belaka, melainkan lebih berupa modal atau aset bagi institusi atau organisasi. Selain itu, dalam organisasi modern, sumber daya manusia mempunyai peran baru, di antaranya: (1) pendorong produktivitas; (2) membuat perusahaan menjadi lebih tanggap terhadap inovasi produk dan perusahaan teknologi; (3) menghasilkan jasa pelanggan yang unggul; (4) membangun komitmen karyawan; dan (5) semakin pentingnya SDM dalam mengembangkan dan mengimplementasikan strategi (Riduan, 2010).

Peranan SDM semakin fokus pada hal-hal yang berhubungan dengan meningkatkan semangat kerja. Semangat kerja merupakan hal yang harus dimiliki oleh setiap karyawan agar produktivitas kerjanya meningkat, oleh karena itu selayaknya setiap perusahaan selalu berusaha agar semangat kerja karyawannya terus meningkat. Dengan semangat kerja yang tinggi, maka dapat diharapkan aktivitas perusahaan dapat berjalan dengan baik sehingga tujuan perusahaan dapat tercapai.

Terkait dengan semangat kerja karyawan, maka penulis tertarik untuk melakukan penelitian pada perusahaan salah satu produsen minyak sawit (CPO) dan inti sawit (kernel) di Provinsi Riau, Indonesia. Perusahaan tersebut berdiri pada awal tahun 1992, awalnya perusahaan ini bergerak di bidang usaha dagang pengolahan dan ekspor vanila. Sebelum berbentuk badan hukum perseroan terbatas, perusahaan ini berbentuk usaha dagang, yang memulai kegiatannya sejak tahun 1986. Setelah dalam beberapa tahun bergerak di usaha dagang pengolahan vanila mengalami kemerosotan maka pihak perusahaan berinisiatif membangun usaha dibidang tanaman kelapa sawit pada tahun 1996 sampai sekarang. Jika merujuk pada teori yang dikemukakan Rivai (2009) menyatakan bahwa salah satu indikasi terjadinya turunnya semangat kerja di kalangan karyawan adalah apabila tingkat ketidakhadiran kerja masih terjadi. Cerminan turunnya semangat kerja berdasarkan ketidakhadiran ini juga terlihat di perusahaan. Berdasarkan data yang penulis dapatkan mengenai perkembangan absensi karyawan pabrik dapat dilihat pada Tabel 1. 
Tabel 1. Data Absensi Karyawan Pabrik

\begin{tabular}{cccccccc}
\hline \multirow{2}{*}{ Tahun } & \multirow{2}{*}{$\begin{array}{c}\text { Hari Kerja } \\
\text { Efektif }\end{array}$} & \multirow{2}{*}{$\begin{array}{c}\text { Jumlah } \\
\text { Karyawan }\end{array}$} & \multirow{2}{*}{$\begin{array}{c}\text { Target } \\
\text { Kehadiran }\end{array}$} & \multicolumn{4}{c}{ Persentase kehadiran (\%) } \\
\cline { 5 - 8 } & & & $(\%)$ & $\mathrm{H}$ & $\mathrm{A}$ & $\mathrm{I}$ & $\mathrm{S}$ \\
\hline 2014 & 300 & 74 & 100 & $93,93 \%$ & $4,14 \%$ & $1,13 \%$ & $0,81 \%$ \\
2015 & 300 & 74 & 100 & $88,69 \%$ & $6,03 \%$ & $1,36 \%$ & $2,93 \%$ \\
2016 & 300 & 79 & 100 & $90,69 \%$ & $3,09 \%$ & $4,23 \%$ & $2,99 \%$ \\
2017 & 300 & 82 & 100 & $86,92 \%$ & $7,14 \%$ & $3,98 \%$ & $1,96 \%$ \\
2018 & 300 & 87 & 100 & $84,57 \%$ & $8,46 \%$ & $3,91 \%$ & $3,07 \%$ \\
\hline
\end{tabular}

Sumber: Data Olahan

Berdasarkan Tabel 1 diketahui bahwa tingkat absensi karyawan pabrik belum seperti yang diharapkan dan bersifat fluktuatif setiap tahunnya. Dengan memperhatikan tingkat absensi karyawan, maka dapat diketahui bahwa semakin rendah kehadiran karyawan, menunjukkan rendahnya semangat kerja karyawan. Jika hal ini dibiarkan maka akan menjadi penghambat pencapaian tujuan perusahaan.

Semangat kerja atau dalam istilah asingnya disebut morale merupakan hal yang harus di miliki oleh setiap karyawan agar produktivitas kerjanya meningkat, oleh karena itu selayaknya setiap perusahaan selalu berusaha agar semangat kerja karyawannya meningkat. Dengan semangat kerja yang tinggi, maka dapat di harapkan aktivitas perusahaan dapat berjalan dengan baik sehingga tujuan perusahaan dapat tercapai.

Berikut pengertian semangat kerja yang dikemukakan oleh para ahli. Darmawan (2007) mengatakan semangat kerja diartikan sebagai semacam pernyataan ringkas dari kekuatan-kekuatan psikologis yang beraneka ragam yang menekan sehubungan dengan pekerjaan mereka. Semangat kerja juga dapat diartikan juga sebagai iklim atau suasana kerja yang terdapat di dalam suatu organisasi yang menunjukkan rasa kegairahan di dalam melaksanakan pekerjaan mendorong mereka untuk bekerja secara lebih baik dan lebih produktif.

Hasibuan (2008) mengemukakan sebagai keinginan dan kesungguhan seseorang mengerjakan pekerjaan dengan baik serta berdisiplin untuk mencapai hasil yang maksimal. Dan Nurmansyah (2011) mengemukakan bahwa melakukan pekerjaan secara lebih semangat sehingga pekerjaan akan dapat diharapkan lebih cepat dan lebih baik. Bedasarkan pengertian para ahli dapat disimpulkan bahwa semangat kerja adalah suatu ekspresi dan mental indidvidu atau kelompok yang menunjukan rasa senang dan bahagia dalam melakukan pekerjaannya, sehingga merasa bergairah dan mampu bekerja secara lebih cepat dan lebih baik demi tercapainya tujuan kelompok maupun organisasi.

Berikut adalah beberapa indikator semangat kerja yang dikemukakan oleh Nitisemito (2008), diantaranya adalah sebagai berikut: (a) Naiknya produktivitas karyawan. Karyawan yang semangat kerjanya tinggi cenderung melaksanakan tugas-tugas sesuai waktu, tidak menunda pekerjaan dengan sengaja, serta mempercepat pekerjaan, dan sebagainya. Oleh kerena itu harus dibuat standar kerja untuk mengetahui apakah produktivitas karyawan tinggi apa tidak. (b) Tingkat Absensi yang rendah. Tingkat absensi yang rendah merupakan salah satu indikasi meningkatnya semangat kerja karena, Karena nampak bahwa persentase absen seluruh karyawan rendah. (c) Labour Turn-over yang menurun. Tingkat karyawan 
keluar masuk karyawan yang menurun merupakan salah satu indikasi meningkatnya semangat kerja. Hal ini dapat disebabkan oleh kesenangan mereka bekerja pada perusahaan tersebut. Tingkat keluar masuk karyawan yang tinggi dapa mengganggu jalanya perusahaan. Selanjutnya, (d) tidak terjadi atau berkurangnya kegelisahan. Semangat kerja karyawan akan meningkat apabila mereka tidak gelisah. Kegelisahan dapat dilihat melalui bentuk keluhan, ketidaktenangan bekerja, dan hal-hal lainya.

Stres kerja merupakan suatu tanggapan adapatif, dibatasi oleh perbedaan individual dan proses psikologis, yaitu konsekuensi dari setiap kegiatan (lingkungan), situasi atau kejadian eksternal yang membebani tuntutan psikologi atau fisik yang berlebihan terhadap seseorang di tempat individu tersebut berada. Stres yang positif disebut eustress sedangkan stress yang berlebihan dan bersifat merugikan disebut distress.

Mangkunegara (2008), mengatakan stres kerja adalah suatu perasaan tertekan yang dialami karyawan dalam menghadapi pekerjaan. Stres kerja ini tampak dari sindrom, antara lain emosi tidak stabil, perasaan tidak tenang, suka menyendiri, sulit tidur, merokok yang berlebihan, tidak bisa rileks, cemas, tegang, gugup, tekanan darah meningkat dan mengalami gangguan penceranaan.

Sopiah (2008) mengatakan stres merupakan suatu respon adaptif terhadap suatu situasi yang dirasakan menantang atau mengancam kesehatan seseorang. Rivai (2009) mengatakan stres kerja adalah suatu kondisi ketegangan yang menciptakan adanya ketidakseimbangan fisik dan phisikis, yang mempengaruhi emosi, proses berpikir dan kondisi seorang karyawan.

Berdasarkan definisi para ahli dapat disimpulkan bahwa stres kerja merupakan suatu kondisi yang merefleksikan rasa tertekan, tegang, yang mempengaruhi emosi dan proses berpikir seorang karyawan untuk mengerjakan pekerjaannya sehingga menghambat tujuan organisasi.

Indikator-indikator stres kerja menurut Robbins dan Judge (2008), dapat dibagi dalam tiga aspek yaitu (1) indikator secara psikologis, yang meliputi cepat tersinggung, tidak komunikatif, banyak melamun, dan lelah mental. (2) indikator pada fisik, meliputi meningkatnya detak jantung dan tekanan darah, mudah lelah secara fisik, pusing kepala, dan problem tidur (kebanyakan atau kekurangan tidur). Kemudian, (3) indikator pada perilaku, meliputi merokok berlebihan, menunda, atau menghindari pekerjaan, perilaku sabotase, serta perilaku makan yang tidak normal (kebanyakan atau kekurangan).

\section{Konflik Kerja}

Pada dasarnya konflik bermula pada saat satu pihak dibuat tidak senang oleh pihak lain mengenai suatu hal yang oleh pihak pertama dianggap penting. Konflik di perusahaan terjadi dalam berbagai bentuk dan corak, yang merintangi hubungan individu dengan kelompok. Adanya perbedaan pandangan diantara setiap orang berpotensi menyebabkan terjadinya pergesekan, sakit hati dan lain- lain.

Konflik di dalam pekerjaan juga di sebut, segala macam interaksi pertentangan atau antagonistik antara dua orang atau lebih di dalam perusahaan. Konflik di dalam kegiatan perusahaan timbul karena adanya kenyataan bahwa mereka harus membagi sumber daya, sumber daya yang terbatas atau kegiatan- kegiatan kerja dan adanya kenyataan bahwa mereka mempunyai perbedaan status, tujuan dan nilai persepsi. Konflik di dalam perusahaan tidak bisa dielakkan tetapi bisa 
diminimalisir untuk tujuan-tujuan perusaahan agar karyawan berpikir kritis, apatis dan produktif.

Rivai (2009) mengatakan konflik kerja adalah ketidaksesuaian antara dua atau lebih anggota-anggota atau kelompok (dalam suatu organisasi/perusahaan) yang harus membagi sumber daya yang terbatas atau kegiatan-kegiatan kerja dan atau karena kenyataan bahwa mereka mempunyai perbedaan status, tujuan, nilai atau persepsi. Rahim (2011) mengatakan konflik adalah suatu proses interaktif yang termanifestasi dalam hal-hal seperti ketidakcocokan, ketidaksetujuan, atau kejanggalan baik intra individu maupun sosial seperti kelompok ataupun organisasi.

Berdasarkan pengertian para ahli dapat disimpulkan bahwa konflik kerja adalah ketidaksesuaian antara dua orang atau lebih di dalam perusahaan karena adanya perbedaan pendapat, nilai-nilai, tujuan, serta kompetisi untuk memperebutkan posisi dan kekuasaan menurut sudut pandang masing-masing untuk mencapai tujuan organisasi.

Untuk menunjang penelitian ini perlu mengetahui indikator konflik (Wirawan, 2010) seperti berdebat dan membantah; berpegang teguh pada pendirian; penilaian pendapat; menyatakan posisi secara jelas; kemampuan memperbesar kekuasaan diri sendiri; kemampuan memperkecil kekuasaan lawan konflik; dan taktik mempengaruhi. Selanjutnya perlu pula diketahui indikator konflik kerja (Flippo, 2011) yaitu percekcokan atau perdebatan (kontroversi); ketegangan masalah pribadi; visi yang berbeda dalam pekerjaan, perbedaan pendapat, perbedaan menentukan penyebab permasalahan, perbedaan dalam menentukan solusi permasalahan; perbedaan dalam menentukan cara penyelesaian konflik; konflik emosional; perselisihan pribadi, dan; lelah secara mental dengan pekerjaan.

Pada penelitian terkait kinerja sumber daya manusia di perusahaan, penulis akan menjawab rumusan masalah Bagaimana pengaruh stres kerja dan konflik kerja terhadap semangat kerja karyawan pabrik secara simultan? Bagaimana pengaruh stres kerja terhadap semangat kerja karyawan pabrik? Akhirnya akan mencoba menjawab Bagaimana pengaruh konflik kerja terhadap semangat kerja karyawan pabrik?

Untuk menyelesaikan permasalahan tersebut penulis menyusun artikel ini menjadi pendahuluan, metode penelitian, hasil dan pembahasan, dan diakhiri dengan kesimpulan. Berikutnya akan disampaikan metode yang digunakan untuk mencapai tujuan studi.

\section{METODE PENELITIAN}

\section{Kerangka Penelitian}

Berdasarkan uraian studi literasi pada bagian sebelumnya dapat digambarkan kerangka penelitian ini pada Gambar 1. 


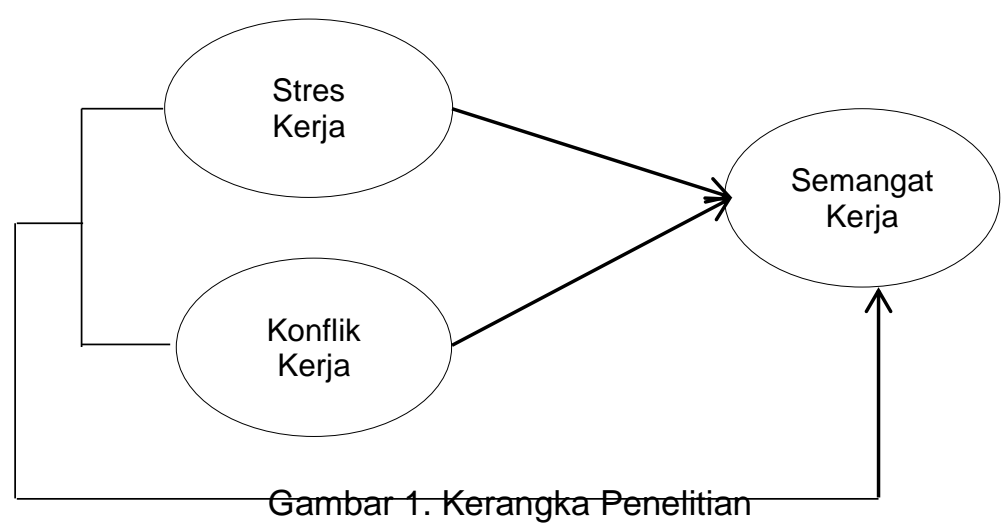

Berdasarkan perumusan masalah serta kerangka penelitian di atas, maka hipotesis yang diuji pada penelitian ini adalah:

$\mathrm{H}_{1}$ : Stres kerja dan konflik kerja berpengaruh terhadap semangat kerja karyawan

$\mathrm{H}_{2}$ : Stres kerja berpengaruh terhadap semangat kerja karyawan

$\mathrm{H}_{3}$ : Konflik Kerja berpengaruh terhadap semangat kerja karyawan

\section{Pengumpulan Data}

Populasi dalam penelitian ini adalah karyawan yang berjumlah 87 orang. Metode menentukan jumlah sampel dilakukan dengan cara sensus, yaitu menjadikan seluruh anggota populasi menjadi sampel (Arikunto, 2010). Sehingga jumlah sampel yang akan menjadi objek penelitian penulis adalah sebanyak 87 orang.

Alat yang digunakan untuk menjaring data tentang stres kerja dan konflik kerja terhadap semangat kerja adalahwawancara, yaitu melakukan tanya jawab langsung dengan responden yang terkait tentang pengaruh stres kerja dan konflik kerja terhadap semangat kerja karyawan. Selain mengumpulkan data melalui wawancara, studi ini juga menggunakan kuesioner. Kuesioner merupakan alat untuk pengumpulan data dengan cara menyusun daftar pertanyaan dan selanjutnya menyebarkannya kepada responden dalam penelitian ini. Adapun angket yang disusun dengan indikator penelitian yaitu tentang pengaruh stres kerja dan konflik kerja terhadap semangat kerja karyawan.

\section{Metode Analisa Data}

Dalam penelitian ini model dan teknik analisa data menggunakan pendekatan analisis regresi linier berganda. Sebelum dilakukan analisis regresi berganda terlebih dahulu dilakukan uji kualitas instrumen penelitian dan uji asumsi klasik, dan hipotesis yang diolah menggunakan program Statistical Program Society Science (SPSS) versi 17 untuk Windows.

\section{HASIL PENELITIAN DAN PEMBAHASAN}

Hubungan variabel stres kerja dan konflik kerja terhadap semangat kerja didapat dengan model persamaan regresi berganda yaitu $\mathrm{SK}=6,807-0,307 \mathrm{SK}-$ $0,341 \mathrm{KK}+$ e. Persamaan ini diperoleh dari hasil Analisa SPSS yang terter a pada Tabel 2. 
Tabel 2. Hasil Analisa SPSS

\begin{tabular}{|c|c|c|c|c|c|c|}
\hline \multicolumn{7}{|c|}{ Coefficients $^{\mathrm{a}}$} \\
\hline & \multirow{2}{*}{ Model } & \multicolumn{2}{|c|}{$\begin{array}{l}\text { Unstandardized } \\
\text { Coefficients }\end{array}$} & \multirow{2}{*}{$\begin{array}{c}\begin{array}{c}\text { Standardized } \\
\text { Coefficients }\end{array} \\
\text { Beta }\end{array}$} & \multirow[t]{2}{*}{$\mathrm{t}$} & \multirow[t]{2}{*}{ Sig. } \\
\hline & & $\mathrm{B}$ & Std. Error & & & \\
\hline \multirow[t]{3}{*}{1} & (Constant) & 6.807 & .267 & & 25.527 & .000 \\
\hline & Stres Kerja & -.307 & .072 & -.397 & -4.273 & .000 \\
\hline & Konflik Kerja & -.341 & .074 & -.429 & -4.619 & .000 \\
\hline
\end{tabular}

Dapat diartikan angka-angka pada persamaan regresi tersebut Nilai konstanta (a) sebesar 6,807 adalah apabila variabel stres kerja dan konflik kerja diasumsikan nol (0), maka semangat kerja sebesar 6,807. Sementara nilai koefisien regresi variabel stres kerja sebesar -0,307, dimana artinya setiap meningkatnya stres kerja sebesar satu satuan maka akan menurunkan semangat kerja sebesar 0,307 dan begitupula sebaliknya, tentunya dengan asumsi variabel lain tetap.

Begitupula dengan nilai koefisien regresi variabel konflik kerja sebesar -0,341. Artinya setiap meningkatnya konflik kerja sebesar satu satuan maka akan menurunkan semangat kerja sebesar 0,341 dan sebaliknya dengan asumsi variabel lain tetap. Kemudian standar error (e) merupakan variabel acak dan mempunyai distribusi probabilitas yang mewakili semua faktor yang mempunyai pengaruh terhadap Y. Tetapi hal ini tidak dimasukkan ke dalam persamaan.

Studi ini menunjukkan stres kerja dan konflik kerja berpengaruh secara simultan terhadap semangat kerja karyawan. Yang artinya stres kerja dan konflik kerja secara bersama-sama berpengaruh terhadap semangat kerja karyawan. Hal ini terjadi karena karyawan belum mampu bertanggung jawab terhadap pekerjaan. Ini ditunjukkan dengan tingkat kehadiran yang rendah dan karyawan belum mampu menyelesaikan tugas yang diberikan dengan tepat. Hal ini menunjukkan semangat kerja karyawan belum cukup maksimal.

Berdasarkan hasil pengujian analisis data diperoleh bahwa stres kerja berpengaruh negatif dan signifikan secara parsial terhadap semangat kerja karyawan. Yang artinya apabila stres kerja meningkat maka akan mengurangi semangat kerja karyawan dan sebaliknya apabila stres kerja berkurang maka semangat kerja karyawan akan meningkat. Stres kerja karyawan pada perusahaan masih terlihat cukup tinggi, hal ini dikarenakan masih adanya karyawan yang sering lalai menyelesaikan pekerjaan, adanya kepuasan kerja yang rendah dan karyawan merasa mudah lelah secara fisik.

Berdasarkan hasil pengujian analisis data diperoleh bahwa konflik kerja berpengaruh negatif dan signifikan secara parsial terhadap semangat kerja karyawan. Yang artinya apabila konflik kerja meningkat maka akan mengurangi semangat kerja karyawan dan sebaliknya apabila konflik kerja berkurang maka semangat kerja karyawan akan meningkat. Konflik kerja karyawan pada perusahaan masih terlihat tinggi, hal ini dikarenakan karyawan merasa terlalu banyaknya tuntutan tugas, dan masih adanya sifat mempengaruhi antar sesama karyawan untuk saling menjatuhkan upaya memperebutkan jabatan tertentu.

Dari hasil tanggapan responden terhadap semangat kerja karyawan diketahui nilai terendah terdapat pada indikator tanggung jawab pekerjaan. Dikutip dari Nik Abdullah (2019) untuk dapat memperoleh keunggulan kompetitif, organisasi mampu mengelola sumberdaya untuk mewujudkan visinya. Pada studi ini, sumber daya manusia memegang peranan penting. Untuk itu, pada kegiatan operasional, 
diharapkan kepada perusahaan agar memberi tugas dan tanggung jawab kepada karyawan dengan batas waktu tertentu. Dan berilah sanksi apabila karyawan tidak bisa menyelesaikan tugasnya dalam waktu yang telah ditentukan. Sehingga dengan hal ini karyawan akan lebih bertanggung jawab dengan pekerjaannya.

Dari hasil tanggapan responden terhadap stres kerja diketahui nilai tertinggi terdapat pada indikator kepuasan yang rendah dalam menyelesaikan pekerjaan. Untuk itu diharapkan kepada perusahaan agar memberikan motivasi kepada karyawan dalam bentuk dorongan untuk terus bersemangat dalam bekerja atau dengan cara memberikan insentif atau bonus. Insentif atau bonus yang adil membuat karyawan berpikir bahwa perusahaan memberi hak karyawan secara profesional. Sehingga dengan hal ini karyawan akan lebih rajin dalam menyelesaikan tugasnya.

Dari hasil tanggapan responden terhadap konflik kerja diketahui nilai tertinggi terdapat pada indikator banyaknya tuntutan tugas dan taktik mempengaruhi dan menjatuhkan karyawan lain, sehingga membuat semangat kerja karyawan selalu menurun. Untuk itu diharapkan kepada perusahaan agar mengurangi dan memberi tugas yang sewajarnya sesuai dengan kemampuan karyawan. Sejalan dengan Andreas dan Natariasari (2019) yang mengungkapkan perusahaan perlu untuk merencanakan penggunaan sumberdaya. Hal ini tentunya akan mengorganisir keperluan sumber daya manusia terhadap pos unit produksi di perusahaa. Melalui sistem perencanaan sumberdaya perusahaan (Enterprise Resource Planning, ERP) keperluan untuk menambah karyawan dapat segera dievaluasi dan membantu perusahaan untuk mengambil keputusan.

\section{KESIMPULAN}

Berdasarkan hasil penelitian yang telah dilakukan oleh penulis pada uraian sebelumnya mengenai pengaruh stres kerja, konflik kerja terhadap semangat kerja karyawan, maka dapat diambil kesimpulan stres kerja dan konflik kerja secara bersama-sama berpengaruh terhadap semangat kerja karyawan. Jelas hal ini perlu dikelola dengan baik oleh perusahaan sehingga semangat kerja karyawan tetap terjaga. Ditambah pula stres kerja yang meningkat ternyata akan mengurangi semangat kerja karyawan, hubungan antara dua hal ini jelas berbanding terbalik. Sejalan dengan stres kerja, konflik kerja yang meningkat juga mengurangi semangat kerja karyawan.

Pada penelitian selanjutnya, diharapkan agar dapat melakukan kajian yang lebih dalam lagi mengenai stres kerja, konflik kerja, dengan menambahkan variabelvariabel lain yang mungkin dapat mempengaruhi semangat kerja karyawan selain variabel-variabel independen tersebut di atas.

\section{UCAPAN TERIMA KASIH}

Penulis menyampaikan terimakasih kepada Fakultas Ekonomi dan Bisnis, Universitas Riau, yang telah memberikan peluang bagi penulis untuk dapat berkarya, belajar, dan menyelesaikan riset dengan baik. Kepada editor yang telah banyak memberi masukan dan dua orang reviewer yang turut berkontribusi memberi peninjauan terhadap artikel ini hingga layak dipublikasikan. 


\section{DAFTAR PUSTAKA}

(1) Andreas, \& Natariasari, R. (2019). Satisfaction ERP Systems: Impact on End-User. Indonesian Journal of Economics, Social, and Humanities, 1(1), 59-63. https://doi.org/10.31258/ijesh.1.1.6

(2) Arikunto, S. (2010). Prosedur penelitian: Suatu Pendekatan Praktik (Edisi Revisi). Jakarta, Indonesia: PT Rineka Cipta

(3) Darmawan, D. (2007). Teori Motivasi. Surabaya, Indonesia: Metromedia Education

(4) Flippo, E.B. (2011). Manajemen Personalia. Jakarta, Indonesia: PT Gelora Askara Pratma

(5) Hasibuan, M.S.P. (2008). Manajemen Sumber Daya Manusia (Edisi Revisi). Jakarta, Indonesia: PT Bumi Aksara

(6) Mangkunegara, A.P. (2008). Manajemen Sumber Daya Manusia Perusahaan. Bandung, Indonesia: PT Rosda

(7) Nik Abdullah, N. (2019). Gaining competitive advantage through new product development capability in Malaysian Government Linked Companies. Indonesian Journal of Economics, Social, and Humanities, 1(1), 37-49. https://doi.org/10.31258/ijesh.1.1.4

(8) Nitisemito, A.S. (2008). Manajemen Personalia, Edisi kedua. Jakarta, Indonesia: Ghalia

(9) Nurmansyah. (2011). Manajemen Sumber Daya Manusia Suatu Pengantar. Pekanbaru, Indonesia: Unilak Press

(10) Rahim, M.A. (2011). Managing Conflict in Organizations (4th Edition). New Jersey, United States of America: Transaction Publisher

(11) Riduan. (2010). Metode \& Teknik Menyusun Proposal Penelitian. Bandung, Indonesia: Alfabeta

(12) Rivai, V. (2009). Manajemen Sumber Daya Manusia untuk Perusahaan dari Teori ke Praktek. Jakarta, Indonesia: Murai Kencana

(13) Robbins, S.P., \& Judge, T.A. (2008). Perilaku Organisasi Edisi 12 Buku 2. Jakarta, Indonesia: Salemba Empat

(14) Sopiah. (2008). Perilaku Organisasi. Yokyakarta, Indonesia: CV Andi Jakarta, Indonesia: Salemba Humanika

(15) Wirawan. (2010). Konflik dan Manajemen Konflik: Teori. Aplikasi, dan Penelitian. Jakarta: Salemba Humanika. 